\title{
Criminal Policy as a Basis for the Sustainable Development or Public Security
}

\author{
Andrejs Vilks ${ }^{1}$
}

\begin{abstract}
Sustainable development of public security should be based on a balanced, rational and effective criminal justice policy. Criminal justice policies can be perceived, valued and also implemented as a set of scientific theories and concepts on the conceptual, strategic and tactical elements of preventing and combating crime and other anti-social phenomena. The fight against crime can be recognized as an element of the cultural environment. It is not possible to achieve the effective functioning of society and its legal system without relying on general human norms and values. The criminal justice approach reflects the common values of the society, which are directed to the interests primarily protected. Criminal justice policy is concerned with the detection of criminogenic processes, crime, their determinants and the effectiveness of measures to prevent and combat crime.
\end{abstract}

Keywords: Crime, Criminal policy, societal development, public security

\section{Intruduction}

Sustainable societal development is possible in an environment where there is no clear threat to its successive evolution and there are sufficient operational conditions. The greatest threats to public security are related to criminal acts: organized crime, terrorism, trafficking in human beings and their organs, drug and arms smuggling, cyber threats. Despite the continuous increase in resources for public and national security, the use of new technologies to strengthen public security does not reduce the level of threats. Security is a support of successful development and welfare of any country, the reason of which is the people's fear of physical, property, sexual, moral, intellectual and other kind of threats. Responsibility of the government and its corresponding institutions is to provide stability of any individual, as well as the public system. Crime and other violations of the law cause irreparable harm both for separate public representatives, as well as for the public and civilization at large. Thus, since the time when the mankind began to be aware of these deviations from the generally accepted ones and violations, the machanisms and forms were developed how to protect oneself against violation and how to prevent it. The term "Criminal policy” in the legal vocabulary is not commonly encountered. Much rarer that the notion „Criminal justice”. It might be due to two interrelated reasons: firstly, the term mentioned is not sufficiently popular, as well as admitted in the legal lexicon; secondly, it may be that in In European law Science there are certain difficulties by forming and realizing the legal policy in the system of legal procedure. It is logical that the first cause of the low usability and popularity of criminal policy is connected with the group of second factors - the legal policy at large, as well as the government (policy) mechanism could be at a much higher level; the government, including the field of criminal proceedings, could be more visible, 
more resultative, as well as more effective. Analyzing the place and importance of criminal policy in the total political system, one can come across various views of the place and status of criminal policy in the whole political structure of the public administration, as well as the content and nature of the term mentioned.Without doubt, depending on stating the place of criminal policy in the whole political system, as well as content, one could formulate the aims, objectives, principles, methods of criminal policy and the prospects for its further development.

It is noted in criminal theory that, - "We live on a daily diet of criminal justice narratives and images in which criminalisation and penalisation are mostly depicted as tied to the nation state. In reality, crimes cross borders easily and increasingly take place at least partially in cyber space. In a 'world in motion' in which products, services and people cross borders all the time, crime is all but an exception" (Future of EU Criminal Justice Policy, 2019) This should be taken into account when identifying criminal justice policies and sustainable development of society.

\section{Methodology}

The theoretical aspects of criminal justice policy will be explored using the descriptive (descriptive) method, through which the content of the concept, its development, its relation to the sustainable development of society will be analyzed. The author uses the analysis of political planning documents and the results of optional studies in the article, making their comparative research.

\section{Results}

The legal literature mentions that the term , criminal policy” for the first time was used in 1804 by a German specialists in law Paul Johann Anselm Feuerbach (Feuerbach 1810). P.A.Feuerbach had doubtlessly a great importance in working out the fundamentals of criminal policy. At the beginning of the 19th century he published a very significant textbook in criminal law in which there was also included the Draft Criminal Code in perspective, which was in detail analyzed using the Roman law. The draft mentioned was approved as German Penal Code (statute) in 1813. In the cycle of criminal science, P.A.Feuerbach identified criminal policy, criminal psychology and penal philosophy as independent fields of epistemology. In the criminal policy aspect P.A.Feuerbach paid a special attention to the importance of penalty. According to the idea of the founder of criminal policy as a science the wish to commit a crime may come to an end when the evil of the offence (penalty) can be greater than the unsatisfied need which is at the basis of the offence. Penalty, according to P.A.Feuerbach, was divided into two groups: threatening penalty and the enforceable penalty. In the first case penalty has a general preventive meaning to deter individuals from a criminal conduct due to a possible sentence realization in future. In the second case the meaning of penalty was connected with the fact that penalty was enforced and the guilty person was punished in correspondence with the norms of criminal proceedings. enal system and the practice of its application in general had to correspond to the political viewpoint on the basis of the statements mentioned. It was important to establish the penal system which could 
prevent a certain part of the society from committing criminal offences, as well as penal institutions haveing the possibility to impose effective sanctions.

In the criminal law theory are encountered various approaches, revealing the notion and nature of criminal policy. Thus, for example, M.Voronin differentiates the nature of criminal policy by three levels: a) wide spectre of measures, starting from those of criminal law and ending with measures for public social development; b) criminal policy is the package of measures addressing the social prevention of the crime, including the actions which affect its determinants, as well as the practice of application of measures of criminal law; c) Criminal policy is the package of measures which include the measures affecting the criminal law crimes (Voronin 2000). But the realization level of the criminal policy can be differentiated also in a slightly different way. the criminal policy, depending on the coverage level of feasible measures can be differentiated as: global, regional, national and administratively territorial which are implemented in definite towns, counties and civil parishes. Analyzing the place and importance of criminal policy in the total political system, one can come across various views of the place and status of criminal policy in the whole political structure of the public administration, as well as the content and nature of the term mentioned. Analyzing the place and importance of criminal policy in the total political system, one can come across various views of the place and status of criminal policy in the whole political structure of the public administration, as well as the content and nature of the term mentioned.Without doubt, depending on stating the place of criminal policy in the whole political system, as well as content, one could formulate the aims, objectives, principles, methods of criminal policy and the prospects for its further development. The Finnish criminal policy is based on the idea of a welfare society, according to which securing the wellbeing, education and employment of the population is the cornerstone of a safe society (The Finnish Ministry of Justice). The basic idea behind this is that people are less likely to commit crimes if they do well. The objective of criminal policy is to reduce criminality and its harmful effects. Crime prevention efforts are the primary means for achieving this. Another objective is to increase safety and sense of security in society. According to the approach of the Finnish Ministry of Justice in its widest sense, criminal policy refers to all actions that have an effect on criminality. Criminal policy includes, for example, decision-making concerning which acts constitute punishable offences, what kind of punishments are imposed for these offences, and how severe these punishments are. In addition to criminal law measures, alcohol policy measures, social and education policy measures, health care service arrangements and urban planning, among other things, affect criminality. Such an approach determines the sustainable development of public security. Finnish criminologist Kauko Aromaa admits that, the objectives of criminal policy are defined being fourfold: 1) to minimise tha social costs of crime; 2) to minimise the costs of crime control; 3) to distribute these costs; and 4) to do this in a fair manner. It is such considerations that are to be accounted for if knowledge-based criminal policy is to be defined and implemented (Aromaa, 2014). He believes that, Crime policy is often mistakenly conceived as 'the fight against crime'. This view is realistic in one respect only: crime is inside and part of the social and legal structure. The well-known Norwegian criminologist Neil Christie (Christie 1993) in his monography „Crime Controlas an industry. Towards GULAGS, Western Style?" admits that he has devoted 
this work to warn the people against adverse tendencies in the fight with crimes in the future. Crime prevention and its combatting are allegorically compared to companies, enterprises and institutions taken together which satisfy the individuals' basic needs in the society, the need for safety, protection against high degree unlawful threats to one's life, health and property,etc. In this context we can say that in the field of ensuring security from criminal threats there practically is no competition observed as a sign of industry (the competence level, rights, duties and responsibility of the police, public procurator, courts and penal institutions do not have any alternatives).

N.Christie admits that the Western society is constantly facing two problems, which are the ground for disorders and crime - inequality in distribution of wealth and total products and inequality in paid work. The industry, in its fight with crime (criminal policy) does not suffer from lack of resources, since there cannot be seen the end of criminal offences, consequently, the demand for legal protection services does not reduce. Price for security and wishes to pay for it increase. Although Christie's work had been written more than ten years ago, we can admit, that the meaning of crime combatting industry has not decreased now either, but has certainly grown up. The demand for legal protection due to criminal offences has increased. The reason for it is the increase in inequality and insufficient provision of paid working places and the amount of salaries, which do not comply with the level of increasing prices. The competence of criminal policy, or that of N.Christie's interpretation of the industry of combatting the crime implies not only optimal development and realization of criminal policy, but also the influence of socioeconomic system, which determines the corresponding crime level, as well as sets for the potential of legal institutions and that of security.Fight with crime by N.Christie is perceived as a public cultural element. According to him one cannot achieve the effectiveness of functioning of rights, not linking them to generally accepted norms and values(6). A useful alternative definition of crime policy was coined by the Finnish crime policy philosopher Patrik Törnudd (Törnudd 1971). According to his approach, criminal policy is: "Decision-making related to crime control - criminal policy or crime control policy - has two basic objectives: 1) to regulate/minimise the sum total of the social costs (including human suffering) caused by crime and by society's response to crime (i.e., crime control); 2) to distribute these costs fairly among the involved parties, i.e., offenders, crime victims, tax payers, etc.". According to this definition, the objectives of crime prevention policy are to: - reduce the social costs of crime and thus ensure the sustainable development of public security. With the exception of the concept of criminal justice policy, terms such as criminal policy are often used in legal literature; policy to prevent and combat crime; social policy in the fight against crime; criminal organizational policy; criminal justice policy. Undoubtedly, each of the above terms has its own content, where, depending on the terms used, the features and essence of the respective concept are also outlined. Policy in the field of crime prevention and combatting, according to its content is the state policy, which might imply also economic, social, educatively informational, administratively organizational and other ideas. Social policy in fight with crime is a set of measures of social character which implies in itself the establishment of territorial planning and refurbishment, building, creation of infrastructural elements, establishing and providing for communication system, taking down socially unfavourable environmental elements 
(slums), care for groups at social risk and disadvantaged population groups. Criminalorganizational policy deals with the management of crime prevention and combatting process and the making of order in institutions and enterprises which are involved in fight with crime (reformation, formation of structural models), perfection of the cooperation, provision of resources and informational base.Criminal justice policy is a sufficiently broad concept, which implies not only the real action in crime prevention and combatting, but implies legal creativity, a package of measures directed towards the self development of the system,etc. A specific term in criminal law policy discourse analysis is criminal policy.It is specific because in many cases the concept mentioned is used as an analogue to the term criminal policy. But such an interpretation can be applied not in all cases. If criminal policy involves the element of justice, the close linkage of the olicy to the existing legal norms, their improvement, assessment of its effectivity, etc, than criminal policy, as to its content, is much broader.In the criminological cognitive process is said that criminal policy is not only the instrument of criminal justice institutions, but also politics, management, strategy and tactics, which is used and is also the base in the criminal structure arsenal. For example, when new joint companies are organized, new goods and services markets are open, new companies coming into a definite region (town, country), when there is a change of criminal policy (decriminalization of some criminal offenses, liberalization or also criminalization, illegal alcohol production and manufacturing business), when there are changes in the structure of legal protection institutions, management,etc., the changes mentioned, as well as many others, they cause respective criminal activities, strategies and tactics of the activities of the respective criminal structures., its determining factors, as well as crime prevention and combatting. Criminologic knowledge and results of specific fundamental and applied research is at the base of adopting effective decisions in the field of criminal policy. To some extent, criminologic knowledge and criminologic policy are at the base of criminal policy and criminal proceeding policy. Amendments to the Criminal law or Criminal procedure Law, first of all, could be based on the study of the effectivity of norm validity and usefulness/ No doubt that by surveying the legal practice, one can conclude which Criminal Law norms or procedural provisions of the law are ineffective, outdated and do not fit criminal reality. Besides, criminologic knowledge, adaptation of corresponding methods are also at the basis of the study of foreign positive experience and positively functioning norms, which can be implemented into the national legal system. However, at the same time we can admit that types of criminal policy, criminal proceeding policy, administratively legal, penal policy,etc. may exist and function independently, first of all, at the theoretically conceptual level, secondly, based on historycally stable traditions. Criminal policy has also its basic concepts, ideas, leading base which we can determined as the basic principles. The basic ideas of the criminal policy depict the principal trends of the state, tasks in the field of crime prevention and combatting. The basic principles of criminal justice policy are as follows: Social conditionality; Scientific validity; Independence; Legitimacy; Humanism; Justice; Publicity; Interaction of national and individual interests; Human rights as a priority. What is the essence of the above mentioned basic principles of criminal policy? Doubtless to say that criminal policy must be socially conditioned. The basic idea of criminal policy comes from and is closely connected to the national or its regional social conditions and ecponomic situation. 
Criminal policy, its basic ideas and strategy must come not from politicians' wishes, but from the corresponding regularities and causal relationship in the society which can be diagnosed only by scientific methods and scientific concept, which states the criminal policy coherence and its scientific validity. Criminal policy has to be sustainable, successive and constant, despite certain political slogans and visions. Criminal policy and its basic concepts have to be accepted and adopted by the respective national institutions for their further realization. Realization of the criminal policy must be not only legitimate - adopted in a legal way, but also its realization has to be guaranteed by means of respective national resources. The basic value of criminal policy is connected with the fact how political statements defend human values - a man, whose rights and legal values are violated, as well as law breaker's interests, envisaging the person's legal protection and responsibility being in line with the existing legal acts. The basic principle of criminal policy deals with one more, to our mind, not less essential aspect, that criminal policy must be really humane to those who stand guard over the law and who daily, correspondingly to their competence and status really participate in undertaking steps in crime prevention and combatting. There is no doubt that criminal policy should be fair both in relation to the victims of violence, and also to the offenders. We have to mention, that at present the legal interests of the offenders in many cases much broader defend the offenders than the persons who had been robbed or raped. Criminal policy has to be worked out openly, providing a wide discussion of the basic statements in the case of necessity organizing discussions and public debates. The acceptance of political statements should be open but their execution - transparent.Criminal policy like any other political sphere is the field of national, public and single individuals' interest interaction. In working out political statements, as well as their realization is mainly guided considering the national interest dominants. What is essential is doubtlessly the fact that politics is the polygon of communication between various interests, their interaction and protection. In single cases in criminal policy a man seems to be completely ignored as to his/her not less important rights. In the hard economic crisis conditions of insolvency process, defending the creditors' interests destroying the families, taking away the property which is later destroyed. As a result, one can admit that in criminal policy the primary items are still an individual person's interests and rights. Consistent taking care of these facts are at the basis of any stable and harmoniously developed country. In criminal policy, its development, realization and correction of political statements a significant meaning belongs to criminal policy methods. In the development of criminal justice policy, we distinguish the following methods: Criminological idea and definite studies in the field of criminal policy; Criminologic modelling and criminal expertises; Development and realization of basic ideas, strategies, programme and plans of multiintegral crime prevention and combatting. We can analize the criminal policy methods, relying on the adequate stages of political element development. One of the first methods and stages in working out criminal policy is the criminological cognition and definite studies in the field of criminal policy. Initial information, its coverage, objectivity and precision on the situation in criminal sphere has a primary meaning in the further activity in the field of assessment, correction and polittechnology creativeness.

Criminal justice policy planning is based on the general principles of social development. 
These are: 1) principle of sustainable development — for present and future generations provides qualitative environment and balanced economic development, rationally uses natural, human and material resources, preserves and develops natural and cultural heritage; 2) principle of aligning the interests - aligns different interests and takes into account the continuity of development planning documents, provides their non duplication; 3) principle of participation - all stakeholders have a chance to participate in development of planning documents; 4) principle of cooperation - state and local government institutions cooperate, meeting the objectives set in development planning documents and informing each other about the aims set and the achievement of the expected outcomes; 5) principle of financial options — assesses the present and medium-term prognosed resources and offers more effective solutions in respect to the necessary costs for the achievemnt of the aims set; 6) principle of openness development planning process is open, and the public is informed on development planning and supportive activities and their outcomes, considering the statutory limitations on the availability of information; 7) monitoring and evaluation principle in the development planning and in the implementation of development planning documents at all government levels there is ensured the evaluation of the impact, as well as monitoring and delivering of surveys on the results achieved; 8) principle of subsidiarity - policy is made by that state or local government institution which is located as possibly closer to the service receivers, and the corresponding measures are effectively implemented as possibly at a lower government level; 9) development planning principle and rulemaking principle of linking - policy is planned prior to issueing the rules and regulations and, by developing the rules and regulation it takes into account the development planning documents; 10) principle of balanced development policy is planned, balancing separate state territory development levels and pace; 11) news principle - development planning documents are updated in accordance to the situation; 12) principle of document coordination - by accepting the development planning document or making amendments in such a document, it ensures making changes in other documents and rules and regulations as well, considering the principle of legal certainty (Act and Latvian Cabinet of Ministers 2008).

In future, to our mind, it is necessary to do criminologic modelling and criminal expertises. In this case we turn the attention to the fact that a new model is being made on the present and acquired information basis, a sample which could change the situation in criminal policy field positively ( to reduce the total number of the recorded offences, the increased number of revealed offences, provided compensation for the damage done,etc.). However, even the further-developed model needs to be subjected to the criminal expertise - whether the recommended new political statements will bring the necessary positive changes in the society? Whether the repeated drug use after decriminalization of the inflicted administrative fine earlier in the year (excluding the criminal liability from the Criminal Law) will bring some positive changes (will allow to economize on police resources? Whether it will desorganize the drug dealers' structures or decrease the drug prices and the demand?). Or may there develop reverse processes in the society - will narcotics subculture develop and progress? Thus, what future is expected by the society undergoing the corresponding criminal changes. It is important to model proper perspective situations and to do the expertise of respective 
amendments.

Methodological provision of criminal policy is going on with working out of multiintegral crime prevention and combatting basis notions, strategy, programme and plans and their realization. The method mentioned deals with the fact that in the development of respective political documents and their realization, is used an interdisciplinary approach by involving scientific staff and practical resources and practitioners of great experience in crime prevention and combatting.

One of the most interesting approaches in developing criminal policy statements and strategies deals with learning of antisocial and criminal factors, working out measures and realizing them in preventing their negative influence which is to a full extent outside the criminalistic sphere (learning of criminal policy background processes). Therefore, everybody may agree that law specialists will not be the most perfect professionals in decreasing of the unemplyment, working out of adequate programmes. The same refers to alcoholism, which is mostly the field of work for health care specialists. Yet, the mentioned methodological approach shows only that all spheres are organically united and interrelated. In the criminal policy development field this fact must certainly be taken into account. The European Union (EU) Commission in the Common Criminal Justice Initiative recognizes that, in order to combat crime effectively, EU criminal justice authorities need to work together (EU Strategy). In a common European area of justice, national law enforcement bodies and judicial authorities need to have confidence and trust in one another.

This will increase people's confidence in the fairness of the proceedings, knowing that their rights are protected when they come to court in another country or are victims of a crime.

Action at EU level is very important for a number of reasons. Serious organized crime is often cross-border. EU legislation should be more coherent to prevent 'safe haven' for criminals; If people can believe that their rights are being respected, they are more likely to use their right to live, work or study in another EU country if they are suspected or accused of crime in all EU countries; Common rules strengthen mutual trust between judicial authorities in different EU countries. This facilitates cooperation and mutual recognition of decisions across the EU; EU criminal law helps to prevent and punish serious offenses, such as environmental crime. For some policy areas it has been established that criminal law measures at EU level are required, while other areas are mentioned as needing further exploration, such as data protection ( Towards an EU Criminal Policy 2011).

An interesting example of criminal justice policy planning is the Estonian Guidelines for the Development of Criminal Policy until 2018, which set out specific long-term goal goals and actions on which the public sector plans and implements operations (Guidelines for Development of Criminal Policy 2010). Upon planning and implementation of criminal policy, the public sector shall cooperate with the private and non-profit sector and involve volunteers. It is the task of the public sector to develop an environment where both, the non-profit and the private sector could fulfil their role in the prevention of offences. The prevention of offences shall, first and foremost, take place at the local level. It is the task of local governments to reduce the factors contributing to offences by involving the local populations and the private and non- 
profit sector. The decisions concerning criminal policy and amendments to legislation shall be based on scientific research and the analysis of high-quality statistics. In order to avoid draft legislation prepared in haste by compromising quality, prior impact studies shall be carried out in case of all the important draft legislation. The E-File processing information system shall be developed continuously in order to obtain high-quality and comprehensive statistics. Criminal policy shall take potential future risks in to account and be ready for the prevention of and responding to problems with racial, ethnical and religious background unknown or rare so far in Estonia such as forced marriages, honour killings, becoming a destination country for trafficking in human beings. Dignified treatment of victims and witnesses in criminal proceedings increases people's trust in the system of legal protection, helps to prevent secondary victimization and alleviate damage caused by criminal offences. Law enforcement agencies and courts shall take measures to prevent secondary victimization of victims and witnesses by criminal proceedings, including avoiding delay of proceedings and ensuring personal data protection. The development and expanding the use of modern types of forensic examination (DNA, IT, etc.) helps to ensure economical criminal proceedings of higher quality which violates less the fundamental rights of persons.

What, however, is the possible future criminal justice policy. An interesting insight into even criminal justice in 20140 is provided by Nancy M. Ritter (Ritter 2006). There's no question that terrorism, the growth of multicultural populations, massive migration, upheavals in age-composition demographics, technological developments, and globalization over the next three or more decades will affect the world's criminal justice systems. The fight against crime can be divided into three categories: reducing crime opportunities, changing the motivation of those who committed crimes, and changing the fundamental values of people, including promoting positive values for young children, in order to reduce the likelihood of future criminal activity. David Weisburd believes that the nature of criminal justice in 2040 will depend in large part on the primary research methodology. Undoubtedly, in the present and future, the development of criminal justice will depend on a science-based cognitive process. It could also ensure the sustainable development of society.

\section{Conclusion}

Criminal policy, depending on the coverage level of feasible measures can be differentiated as: global, regional, national and administratively territorial which are implemented in definite towns, counties and civil parishes. In criminal policy, its development, realization and correction of political statements a significant meaning belongs to criminal policy methods. Analyzing the place and importance of criminal policy in the total political system, one can come across various views of the place and status of criminal policy in the whole political structure of the public administration, as well as the content and nature of the term mentioned. Criminal Law policy is one of the legal policy elements included into the total political system and in its planning mechanism. It is impossible to make comprehensive and thorough analysis of Criminal Law policy not considering the approach to the common national policy planning, national policy formation process, procedure of developing policy documents and 
political technology aspects from the point of view of activities of national government elements. To our mind, two issues are of importance: firstly, what the current policy planning system looks like, including specific signs of criminal policy formation, secondly, - whether the mentioned system is sufficiently constructive and gives a possibility to work out, adopt and be realized in criminal law, as well as other fields, and to achieve the necessary and planned outcome.

\section{References}

Act and Latvian Cabinet of Ministers Regulations (2009). Nr.1178 dated October 13, 2009 „Development planning documents and policies for impact assessment" for development planning and development of respective documents is based on the following basic principles. https://likumi.lv/doc.php?id=270934. Accessed 11/03/2019

Aromaa K. (2014). Responsible criminal policy / Crime and criminal policy. KRIMINOLOGIJOS STUDIJOS 2014/1.p. $\quad 77 . \quad$ File:///C:/Users/User/Downloads/3677-\#\#default.genres.article\#\#-2847-0-1019700101.pdf. Accessed 20/03/2019

Cristi N. (1993),,Crime Controlas an industry. Towards GULAGS, Western Style?”, London, Routledge.

EU strategy on criminal justice. https://ec.europa.eu/info/policies/justice-and-fundamental-rights/criminaljustice/eu-strategy-criminal-justice_en. Accessed 15/03/2019

Guidelines for Development of Criminal Policy until 2018. https://www.just.ee/sites/www.just.ee/files /guidelines_for_development_of_criminal_policy_until_2018.pdf. Accessed 2/04/2019

Feuerbach P.J.A.(1810) Blick auf die deutsche Rechtswissenschaft.

Finnish Ministry of Justice. https://oikeusministerio.fi/en/criminal-policy. Accesed 28/03/2019

Future of EU Criminal Justice Policy and Practice.Legal and Criminological Perspectives (2019).Publisher:Brill Nijhoff. ISBN: 9789004367371. https://brill.com/view/book/edcoll /9789004367371/front-6.xml. Accessed 11/03/2019

Ritter N.M. (2006) Preparing for the Future: Criminal Justice in 2040. NIJ Journal Issue No. 255. https://www.nij.gov/journals/255/pages/2040.aspx. Accessed 1/04/2019

Törnudd, P 1971, 'The Futility of Searching for Causes of Crime' in Scandinavian Stud $\neg$ ies in Criminology, vol. 3, Oslo-Bergen-Tromsö: Universitetsforlaget, pp. 23-33.

Towards an EU Criminal Policy: Ensuring the effective implementation of EU policies through criminal law. https://edps.europa.eu/data-protection/our-work/publications/comments/towards-eu-criminalpolicy-ensuring-effective_en. Accessed 15/03/2019

Voronin. M.J. (2000). Criminal policy: the concept, history, origin and development. Moccow., p.4-11 (Russian language.) 